\title{
Erratum to: A rapid and reliable method for PCR-based amplification of chromosomal and mitochondrial DNA from intact yeast cells
}

\author{
R. Jesenofsky $\cdot$ J. Naehring $\cdot$ K. Wolf
}

Published online: 21 October 2011

(C) Springer-Verlag 2011

Erratum to: Curr Genet (1995) 27:318-319

DOI 10.1007/BF00352100

The family name of the first author R. Jesnowski has meanwhile changed to R. Jesenofsky.

The online version of the original article can be found under doi:10.1007/BF00352100.

R. Jesenofsky $\cdot$ J. Naehring $\cdot$ K. Wolf $(\bowtie)$

Institut für Biologie IV (Mikrobiologie),

Rheinisch-Westfälische Technische Hochschule Aachen,

Worringer Weg, D-52056 Aachen, Germany 